year was a heavy blow which it may be surmised hastened his end. His death leaves a gap which cannot easily be filled, while his many achievements will continue to bear fruit for years to come.

$$
\text { itlo }
$$

H. TEMPaNy

IN my recollectioneSir Frank will remain always as a man possegging the qualities of sympathy, patience and understanding in rare degree. To the Colonial Defeoppment Corporation he was many things sided His good name in the Colonies was a great asset. Ioors opened to him readily. Of knowligdge $\mathrm{en}$ Colonial agriculture, horticulture and topogfaph he was an encyclopædia. Whenever new sflomes were under consideration his mind rapidly stuyed the initial, often daunting, obstacles of pleliminary experiment and investigation. If a new crop were mooted, on new ground, his advice as a starting point was often something like this : "Yes, it should be all right if the rainfall is not higher than 70 in. ; but if, as I suspect, it is 100 in. or more, the crop will suffer from such-and-such disease." There was no consciousness of superior merit in his voice as he imparted his quiet advice, the distilled essence of his own knowledge and life's experience. As an agricultural expert alone, his value to the Corporation was beyond compute; but he was not content to limit his duties even to this broad sphere. As deputy chairman he played a routine part in nearly every scheme which was undertaken. More than that, he served as chairman of the Corporation's subsidiary in East Africa, and the effort of travel in that region in no way discouraged him from fulfilling his obligations there. To the end he remained eager for work-and it is by his work that he will still be remembered long after those who knew him as a sterling colleague and a kind friend have themselves passed away.

TREFGARNE

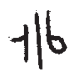

\section{Mr. E. E. Green}

Mr. E. E. GReEN, who died at Camberley on July 2, was well known as an autbority on the Coccidæ and as Government entomofost in Ceylon. No 'expert' employed by the deyldh Government was so well known to the plantil Ommunity as 'Pouchee Green' as he was called. Wouchee' is the Tamil word for an insect. Grgen, whd was born in Ceylon in 1861, was not trained of $\quad$ nentomologist. His father, Mr. John Philip Green, SkColombo, sent him to Charterhouse for lis education. Returning to Ceylon in 1880 , he bechme a tea planter. In 1886 the coffee industry in ceylon was threatened by the green scale bug, a which seemed likely to put an end to the industry. Green, who had an inborn love for natural history, turned his attention to this pest and published a paper on the species, which was printed by the Government of Ceylon.

The Planters' Association was impressed by Green's work, and he was invited to visit estates and advise on methods of dealing with pests, and a few years later, in 1897, Green was appointed Government entomologist. The post was at first honorary, but later he became economic entomologist at the Peradeniya Botanic Gardens. This was his most active period. Being a man with private means, he was able to take leave in England at his own expense, when his studies made this necessary. In 1913 the Ceylon Government placed the scientific officers at Peradeniya under a new department, the Agricultural
Department. Green, who was then fifty and suffering from malaria, retired at this time.

In England, Green settled at Camberley and devoted his time to his favourite group, the Coccidæ. In these he became an international authority and spent much of his time naming collections from all over the world for his numerous correspondents. All this work was done at his own expense, often for Government departments. While intolerant of most professional entomologists, he was extremely helpful and generous to these correspondents. The coloured plates of his great work, the "Coccidæ of Ceylon", were drawn by himself. The book was issued in five parts over a period of twenty-six years and remains his chief monument. His interest in entomology was general and he wrote more than four hundred papers. In 1923 the Royal Entomological Society honoured Green by making him president. He leaves a widow, two sons and a daughter.

\section{Prof. A. Lo Surdo}

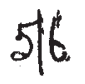

ITALIAN geophysics lost one of its most notable leaders on June 7 with the death, at the age of sixtynine, of Prof. Antonino Lo Surdo, founder and director of the National Institute of Geophysics at Rome. Born in Syracuse, he graduated in physics at Messina. The great Messina earthquake of 1908 robbed him of all his family, save a brother, a loss that cast a shadow of sadness over his whole later life, in which he contracted further family ties. He taught and carriep out Asearch at Messina and, from 1919, at the Unif dry of Rome, where he held the chair of physics ux his death; he gave great attention to expermoental demonstrations in his teaching.

By very deficatemeasurements Lo Surdo disproved Landolt's theory that chemical reactions were accompanied by an appreciable variation of mass; and amgng ot 7 spectroscopic studies, he independently, an abs the same time as Stark, discovered that electric helds affect the spectra of gases emitting radiation. He also worked on interference and other properties of microwaves, on binaural hearing and acoustic physiological properties of the human ear, and on thermionics.

In later life Lo Surdo devoted himself increasingly to geophysies, in many branches. When the Italian National Research Council was initiated at the end of the First World War, he secured the foundation under its auspices of the National Institute of Geophysics, which later became an independent body; it has supported many geophysical stations and projects in Italy, and in particular has greatly developed the Rome seismological station. Very recently he founded the beautifully produced Annali di Geofisica. He was present at last year's assembly of the International Union of Geodesy and Geophysics at Oslo, and those who met him there will grieve to learn of his death.

\section{WE regret to annource the following deaths:}

Dr. G. S. Baker O.B.E., the first superintendent of the William Froude Laboratory, National Physical Laboratory, on August 16, aged seventy-one.

Prof. A. Bgivin, director of the bacteriological lab. oratory of the National Centre of Scientific Research, Strasbourg, on July 10.

Mr. H. O. Newboult, fellow and mathematical tutor of Merton College, Oxford, aged fifty-two. 